\title{
Effect of Spirulina platensis suspension on quality and quantity of sperm and expression of caspase-3 of testis in diabetic wistar rats induced by streptozotocin
}

\author{
Ayu Shabrina ${ }^{1,2}$, Kintoko* ${ }^{1}$, Sapto Yuliani ${ }^{1}$, Adhi Gunawan ${ }^{1}$ \\ ${ }^{1}$ Faculty of Pharmacy, Universitas Ahmad Dahlan, Yogyakarta \\ Jl. Prof. Dr. Soepomo, S.H., Janturan, Yogyakarta \\ ${ }^{2}$ Faculty of Pharmacy, Wahid Hasyim University, Semarang \\ Jl. Menoreh Tengah X/22 Sampangan Semarang
}

Reviewed: $25-08-2018$

Accepted: 25-10-2018

\begin{abstract}
Diabetes is metabolic disorders caused by oxidative stress that has always been linked to male reproductive dysfunction. Spirulina platensis has been used for therapeutic supplements for diabetes and repairing reproduction organs based on its antioxidant effects. The aim of this study was to examine the effect of Spirulina platensis suspension (SP) on quality and quantity of sperm also the expression of caspase-3 on testis in male Wistar rats induced by streptozotocin (STZ). This study used 30 adult male Wistar rats that divided into 6 groups of K1 (normal), K2 (single injection of STZ 45 $\mathrm{mg} / \mathrm{kg} \mathrm{BW}$ ), K3 (normal rats treated with SP 36/kg BW/day) and treatment group K4, K5 and K6 were diabetic rats given with SP $36 \mathrm{mg} / \mathrm{kgBW}, 72 \mathrm{mg} / \mathrm{kgBW}$ and $144 \mathrm{mg} / \mathrm{kg} \mathrm{BW}$. The treatment was given orally for 28 days. Blood glucose level levels were measured using the biochemical analyzer. Quality and quantity of sperm were analyzed using Neubauer slide under the microscope. Apoptosis of Leydig cells was detected by immunohistochemical staining using Caspase-3 polyclonal antibodies. The result showed that there were significant differences between groups $(\mathrm{p}<0.05)$ in final blood glucose level, quality, and quantity of spermatozoa and expression of caspase-3. Our findings clearly highlight the role of Spirulina platensis as an antidiabetes and protective agent for reproducton organs of STZinduced in diabetic male Wistar rats that improves quality and quantity of sperm cells and reproductive organs.
\end{abstract}

Keywords: male infertility, diabetes mellitus, stress oxidative, Spirulina platensis

\author{
*Corresponding author: \\ Kintoko \\ Faculty of Pharmacy \\ Universitas Ahmad Dahlan \\ J1. Prof. Dr. Soepomo, S.H., Janturan, Yogyakarta \\ Email: kkintoko77@gmail.com
}




\section{INTRODUCTION}

Diabetes mellitus is a metabolic disease caused by high levels of oxidative stress in the body and result in impaired reproductive function in men (Karanukaran and Park, 2013). According to the International Diabetes Federation (2011), there are 382 million people suffering from diabetes by 2013 and estimated to be 592 million people by 2035. La Vignera et al., (2012) stated as many as 90\% of patients with diabetes mellitus aged less than 30 years. As many as $51 \%$ of diabetic patients suffer from subfertility). The prevalence of infertility in men with type 2 diabetes mellitus was $35,1 \%$ and as many as $16 \%$ of men with type 2 diabetes mellitus had primary infertility (La Vignera et al., 2012). Delfino et al., (2007) stated that of 500 infertility couples there are people with diabetes mellitus as much as $1.2 \%$. Jungwirth et al. (2015) reported that as many as $15 \%$ of couples are unable to have children within 1 year and $50 \%$ of cases of infertility come from men.

Diabetes mellitus can lead to testicular dysfunction and erectile failure (Srilatha and Muralidhara, 2007). Men with diabetes mellitus have low sperm quality and there is DNA damage to semen due to high oxidative stress in the body (Birben et al., 2012). Men with diabetes mellitus have high sperm cell death rates due to mitochondrial membrane destruction and sperm DNA protein denaturation resulting in infertility (Wang et al., 2013).

The use of herbal remedies as an alternative today can decrease the side effects of diabetes mellitus and preventing complications (Plutzky, 2011). Spirulina platensis is one of the natural plant that has a potential to protect the damage of testicular organs, repair damaged testicular tissue and protect reproductive organs from oxidative stress induced by $\mathrm{HgCl}_{2}$ (El-Dosky et al., 2013). Spirulina platensis is able to stimulate B-pancreatic cells to produce insulin and repair pancreatic tissue (Shazly et al., 2015).

Spirulina platensis contains very high vitamin B12 and up to $70 \%$ protein which is dominated by leucine, valine, and isoleucine amino acids (Al-Dhabi and Arasu, 2016). Spirulina contains vitamin E, phycobilisome, and phycocyanin which have the effect of an antioxidant, anti-inflammatory and anticancer (Firdiyani, 2015). Yigit et al. (2016) mention that Spirulina is able to prevent cell death and improve cell DNA synthesis caused by oxidative stress. Flavonoid and phycocyanin content of $S$. platensis are able to protect Leydig cells in the testes from oxidative damage caused by diabetes mellitus (Hanukoglu, 2006). Vitamin E from Spirulina is able to restore the condition of diabetes and repair damaged testicular tissue due to oxidative stress (Aybek et al., 2008).

\section{MATERIALS AND METHOD \\ Materials \\ Plant material}

Spirulina platensis was obtained PT Neoalgae Indonesia Makmur Sukoharjo in the form of powder. The powder was identified with microscope to assure the microscopic structure of $S$. platensis. A total of $4 \mathrm{~g}$ SP powder was formulated in suspension with PGA $(1,25 \%)$ and CMC-Na $(1 \%)$ as suspending agent and Glycerin $(10 \%)$ as a wetting agent, and aquadest added up to $100 \mathrm{~mL}$.

\section{Chemicals}

STZ was purchased from Nacalai Test Inc. The STZ solution was prepared by freshly dissolving in citrate buffer $(0.01 \mathrm{M}, \mathrm{pH} 4.5)$. All reagents used in study were analytical grade.

\section{Animals}

The study used 30 male Wistar rats aged 3 months with the weight between $150-180 \mathrm{~g}$. The rats were adapted for a week at Laboratory of Pharmacology at Universitas Ahmad Dahlan with adequate feeding, drinking, and lighting at room temperature. Animals were maintained under standard environmental conditions at $45-55 \%$ relative humidity for $12 \mathrm{~h}$, each of dark and light cycle and fed with a standard pellet rats diet. This study was approved by Ethic Comittee of Faculty of Medicine of Muhammadiyah University with number 299/EP-FKIK-UMY/V/2017. 


\section{Methods \\ Induction of diabetes}

Rats were made diabetic by a single dose of STZ at $45 \mathrm{mg} / \mathrm{kg} \mathrm{BW}$ i.p. The blood glucose was checked before and $72 \mathrm{~h}$ after STZ injection to confirm the development of diabetes. Rats which showed blood glucose levels $>250 \mathrm{mg} / \mathrm{dL}$ were separated and used for the study.

\section{Experimental design}

The rats were divided into 6 groups $(\mathrm{n}=5)$ consisting of group 1 (K1 = normal rats), group 2 (K2 = single-dose induced STZ single-dose $45 \mathrm{mg} / \mathrm{kgBW})$, group $3(\mathrm{~K} 3=$ normal rats given SP $36 \mathrm{mg} /$ $\mathrm{kgBW} /$ day), group 4, 5 and 6 (K4, K5, K6 = respectively were diabetic rats given SP 36mg / kgBW / day, $72 \mathrm{mg} / \mathrm{kgBW} /$ day and $144 \mathrm{mg} / \mathrm{kgBW} / \mathrm{day}$ ). Blood glucose was measured with biochemical analyzer using GOD-PAP kit at weekly interval i.e 0, 7, 14, 21 and 28 days after daily administration of SP suspension.

\section{Sperm count}

The number of sperm cells were counted using hemocytometer by taking cement to a scale of 0.5 and phosphate buffer $\mathrm{pH} 7,4$ to 101 . The first droplets were homogenized and discarded. The fluid was drained on the hemocytometer. The analysis was performed by counting the number of sperm cells in 5 large boxes of hemocytometer under a microscope with $40 \mathrm{x}$ magnification.

Concentration $=$ Number of spermatozoa $\times 5 \times$ dilution $\times 10,000$ million spermatozoa $/ \mathrm{mL}$

\section{Motility of sperm}

The sperm motility was subjectively analyzed by the researcher. A total of $20 \mu \mathrm{l}$ of cement was placed on the glass object and covered with a glass cover. Motility was examined under a microscope at 40x magnification. The criteria for motility of spermatozoa are: $0 \%$ : immobile spermatozoa, 50\%: spermatozoa move in circular, less than 50\% progressive and undulating moves; 50-80\%: spermatozoa move progressively and produce mass movement; $90 \%$ : spermatozoa move progressively, agile and waveform; 100\%: movement is very progressive, waveform and very fast (Widodo, 2009)

\section{Organ index}

The organs were dried between two sheets of filter paper and their wet weight was determined. The organ weight/body weight ratio $\times 100$ was calculated and expressed as relative organ weight beside absolute weight

$$
\text { Organ Index (\%) }=\frac{\text { Testis Weight }}{\text { Rats Weight }} \times 100 \%
$$

\section{Immunohistochemistry determination}

Immunohistochemistry procedure was done according to Elgawish and Razak (2014). Testis section were studied under light microscope at 400x magnification to count cells that express caspase3.

\section{Statistical analysis}

All values from each sample $(n=5)$ were expressed as means with \pm S.D. Statistical analysis of data was performed using Kruskal-Wallis followed by Mann Whitney test for comparison of various treatments using the IBM SPSS software (version 17.0, SPSS Inc., Chicago, IL). The difference in statistics at $\mathrm{P}<0.05$ was considered significant. 


\section{RESULT AND DISCUSSION}

STZ is a substance that has selective toxicity in $\beta$-pancreatic cells that can lead to diabetes mellitus conditions in experimental animals through the interference of oxidative stress mechanisms (Papaccio et al., 2000). The induction of STZ at a dose of $45 \mathrm{mg} / \mathrm{kgBW}$ may lead to long-term hyperglycemia conditions that may lead to weight loss of test animals, decreased sperm, organ index and trigger apoptosis of testicular tissue (Won et al., 2012; Jiang et al., 2015). The results of the determination of animal blood glucose level during the treatment can be seen in Figure 1.

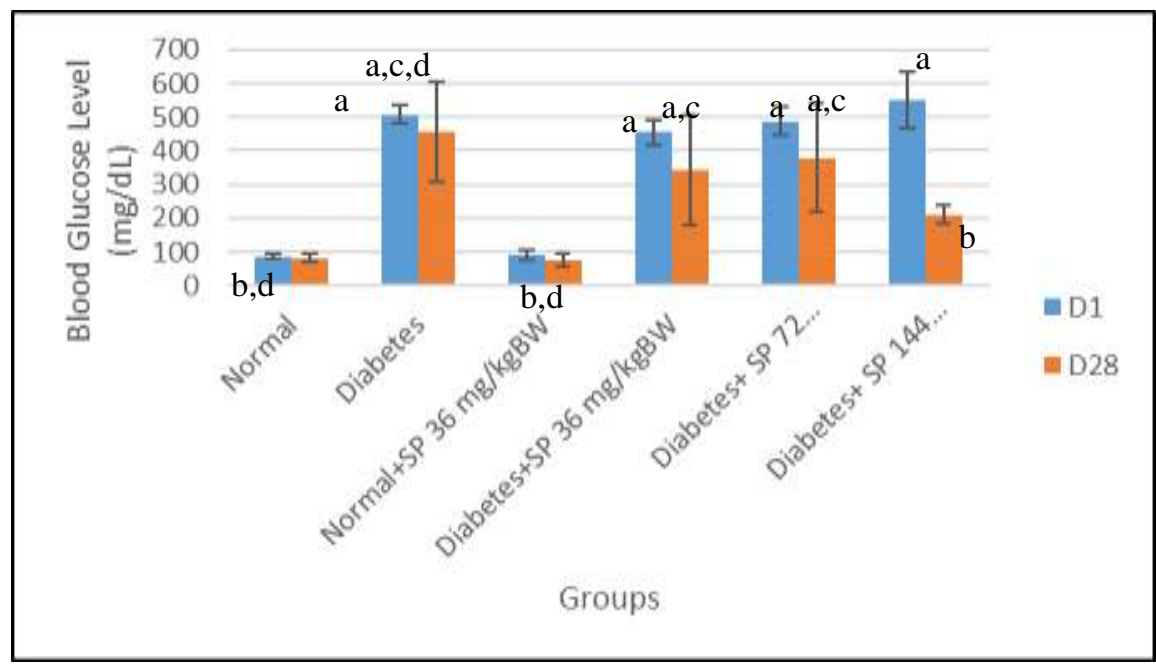

Figure 1. Blood glucose levels of STZ induced Wistar rats treated by Spirulina platensis at day 1 and day 28. Note: (a) $\mathbf{P} \leq \mathbf{0 . 0 5}$ to the normal group; (b) $\mathbf{P} \leq \mathbf{0 . 0 5}$ to the diabetes group; (c) $P \leq 0,05$ to group N + SP 36 / kgBW; (d) P $\leq 0.05$ to the diabetic group + SP $144 \mathrm{mg} / \mathrm{kgBW}$

Spirulina platensis is a microalga that has many pharmacological effects ie antidiabetes (Layam and Reddy, 2007) and antioxidants (Firdiyani, 2015). Spirulina platensis is able to increase the antioxidant enzymes of SOD, GPX and CAT (El-Dosky et al., 2013) and have activity as protective agents against testicular tissue (Won et al., 2012; Bashandy et al., 2016), liver and kidney (Zheng et al., 2013) due to diabetes. Spirulina platensis is consumed as a supplement able to prevent hyperglycemia (Deng and Chow, 2010).

The content of phycobiliprotein, $\beta$-carotene, vitamin E, $\gamma$-linoleic acid and zinc as the main content of Spirulina platensis (Mazo et al., 2004) have antidiabetic effects (Layam and Reddy, 2007). $\beta$-carotene is able to provide Leydig cell protection due to oxidative damage to the P450 system (Hanukoglu, 2006). Vitamin $\mathrm{E}$ is able to protect the testis tissue from free radicals (Aybek et al., 2008). The zinc content of Spirulina platensis acts as a cofactor for SOD that acts as an antioxidant in testicular tissue (Bashandy et al., 2016).

Spirulina platensis at a dose of $144 \mathrm{mg} / \mathrm{kgBW}$ was able to show the greatest decrease in blood glucose level. Suspension of SP in various doses in this study indicates the presence of activity but has not shown any effectiveness as antidiabetes. This is possible due to the lack of number of test animals and time of study. Based on El-Baz et al (2013) and Layam and Reddy (2007) showed that administration of Spirulina platensis dispersed in water at a dose of $15 \mathrm{mg} / \mathrm{kgBW}$ for 45 days was able to decrease the blood glucose levels of the rats $(\mathrm{n}=10)$ below $200 \mathrm{mg} / \mathrm{dL}$ with blood glucose level was the same as the diabetic rats treated by glibenclamide $5 \mathrm{mg} / \mathrm{kgBW}$ for 45 days of treatment.

The antihyperglycemic mechanism of Spirulina platensis through repair of $\beta$-pancreatic cells so that insulin can be secreted and increase blood glucose transport into the tissues (Layam and Reddy, 2015). Layam and Reddy (2015) stated that Spirulina platensis is able to increase NADP + production 
resulting in down-regulation in the process of lipogenesis that can reduce the risk of tissue damage and oxidative stress.

Weight loss in type 1 diabetics are generally lower than normal whereas type 2 diabetes is generally obese (Ozogwu et al., 2013). Tables I shows the body weight of all STZ-induced and normal-group test animals and their alterations.

Table I. Body weight (BW) of test animal on day 1 and day 28 during treatment

\begin{tabular}{lll}
\hline Groups $(\mathrm{n}=5)$ & BW D-1 (gram) & BW D-28 (gram) \\
\hline K1 (N=Normal) & $163.80 \pm 2.86$ & $200.00 \pm 16.01^{\mathrm{b}}$ \\
K2 (D=Diabetes) & $213.20 \pm 9.52$ & $153.00 \pm 13.04^{\mathrm{a}}$ \\
K3 (N+SP 36mg/kgBW) & $153.60 \pm 15.85$ & $209.80 \pm 4.60^{\mathrm{b}}$ \\
K4 (D+SP 36 mg/kgBW) & $181.20 \pm 12.13$ & $119.00 \pm 16.85^{\text {a.c.d }}$ \\
K5 (D+SP 72 mg/kgBW) & $169.20 \pm 1.78$ & $141.20 \pm 21.82^{\text {a.c.d }}$ \\
K6 (D+SP 144 mg/kgBW & $176.20 \pm 6.05$ & $200.60 \pm 64.79^{\mathrm{b}}$ \\
\hline
\end{tabular}

Note: (a) $\mathrm{P} \leq 0.05$ to the normal group; (b) $\mathrm{P} \leq 0.05$ to the diabetes group; (c) $\mathrm{P} \leq 0,05$ to group $\mathrm{N}+$ SP 36 / kgBW; (d) P $\leq 0.05$ to the diabetic group + SP $144 \mathrm{mg} / \mathrm{kgBW}$

The results of this study indicate that diabetic rats and diabetic rats given SP suspension at the dose of $36 \mathrm{mg} / \mathrm{kgBW}$ experienced the highest weight loss compared to other groups. Diabetic rats given with SP suspension at the dose of $144 \mathrm{mg} / \mathrm{kgBW}$ showed the highest weight gain.

Table II. Sperm count, sperm motility, organ index and apoptosis index of tested animal

\begin{tabular}{lllll}
\hline \multicolumn{1}{c}{$\begin{array}{c}\text { Groups } \\
(\mathbf{n = 5})\end{array}$} & $\begin{array}{c}\text { Sperm Count } \\
\left(\mathbf{1 0}^{\mathbf{6}}\right)\end{array}$ & $\begin{array}{c}\text { Sperm Motility } \\
(\mathbf{\%})\end{array}$ & $\begin{array}{c}\text { Organ Index } \\
(\mathbf{\%})\end{array}$ & $\begin{array}{c}\text { Caspase-3 } \\
\text { Positive Cells }\end{array}$ \\
\hline K1(N=Normal) & $69.4 \pm 6.47^{\text {b }}$ & $84.00 \pm 0.016^{\text {b }}$ & $2.84 \pm 0.07^{\text {b.d }}$ & $13.1 \pm 4.39^{\mathrm{b}}$ \\
K2(D=Diabetes) & $32.8 \pm 5.89^{\text {a.c.d }}$ & $68.00 \pm 0.027^{\text {a.c.d }}$ & $1.44 \pm 0.44^{\text {a.c.d }}$ & $41.72 \pm 9.93^{\text {a.c.d }}$ \\
K3 (N+SP 36mg/kgBW) & $71.2 \pm 5.26^{\text {b }}$ & $82.00 \pm 0.027^{\mathrm{b}}$ & $2.81 \pm 0.20^{\mathrm{b}}$ & $17.24 \pm 5.80^{\mathrm{b}}$ \\
K4 (D+SP 36 mg/kgBW) & $39.8 \pm 7.6^{\text {a.c.d }}$ & $79.00 \pm 0.044^{\mathrm{b}}$ & $1.45 \pm 0.57^{\text {a.c }}$ & $34.6 \pm 7.17^{\text {a.c.d }}$ \\
K5 (D+SP 72 mg/kgBW) & $47.4 \pm 4.88^{\text {a.c.d }}$ & $81.00 \pm 0.022^{\mathrm{b}}$ & $1.48 \pm 0.29^{\text {a.c.d }}$ & $33.58 \pm 7.37^{\text {a.c.d }}$ \\
K6 (D+SP 144 mg/kgBW & $60.0 \pm 8.63^{\text {b }}$ & $82.00 \pm 0.025^{\mathrm{b}}$ & $2.18 \pm 0.55^{\text {a.b }}$ & $13.42 \pm 4.12^{\text {b }}$ \\
\hline N
\end{tabular}

Note: (a) $\mathrm{P} \leq 0.05$ to the normal group; (b) $\mathrm{P} \leq 0.05$ to the diabetes group; (c) $\mathrm{P} \leq 0,05$ to group $\mathrm{N}+\mathrm{SP} 36$ / $\mathrm{kgBW}$; (d) $\mathrm{P} \leq 0.05$ to the diabetic group $+\mathrm{SP} 144 \mathrm{mg} / \mathrm{kgBW}$

Table II showed that the number of spermatozoa in diabetic rats decreased significantly compared to the normal group. Diabetic rats given with SP suspension at a dose of $144 \mathrm{mg} / \mathrm{kgBW}$ showed the highest spermatozoa count compared to the diabetes group. This suggests that Spirulina platensis is able to increase the number of possible spermatozoa based on protein content and antioxidant activity of Spirulina platensis (Won et al., 2012).

The sperm motility in group 6 of the tested diabetic specimens of Spirulina platensis with the dose of $144 \mathrm{mg} / \mathrm{kgBW}$ showed the highest percentage of motility compared to groups 4 and 5 , each of which was given Spirulina platensis dose of $36 \mathrm{mg} / \mathrm{kgBW}$ and $72 \mathrm{mg} / \mathrm{kg} \mathrm{BW}$. It is possible that the content of phycocyanin Spirulina platensis capable of inhibiting free radicals that affect sperm motility (Bhat and Madyastha, 2001). Spirulina platensis is able to prevent the decrease of zinc concentration in testicular tissue in which zinc acts as a cofactor for superoxide dismutase that acts as an antioxidant in testicular tissue (Bashandy et al., 2016).

A decrease in testicular weight due to diabetes is associated with a decrease in ATP in the cells of testicular organ cells (Amaral et al., 2006). ATP disturbances in testicular organ cells cause mitochondrial dysfunction so that spermatogenesis and maturation of the epididymis are impaired 
(Amaral et al., 2009). A decrease in testicular weight may decrease sperm count and motility (Sacarano et al., 2006) in accordance with the above results.

Organ index increased in group K6 (diabetic rats given the suspension of SP $144 \mathrm{mg} / \mathrm{kgBW}$ ) was possible due to the antioxidant components contained in Spirulina platensis (Rezvanfar et al., 2008). Spirulina platensis is capable of providing protective effects on male reproductive organs due to diabetes (Won et al., 2012).

Apoptosis of testicular tissue is seen by immunohistochemical staining using caspase-3. A positive Leydig cell expressing caspase-3 shows the brown color on the cytoplasm, whereas the negative Leydig cell that is not expressing caspase-3 exhibits purple. The result of caspase-3 immunohistochemical staining on the testicular tissue can be seen in Figure 2.

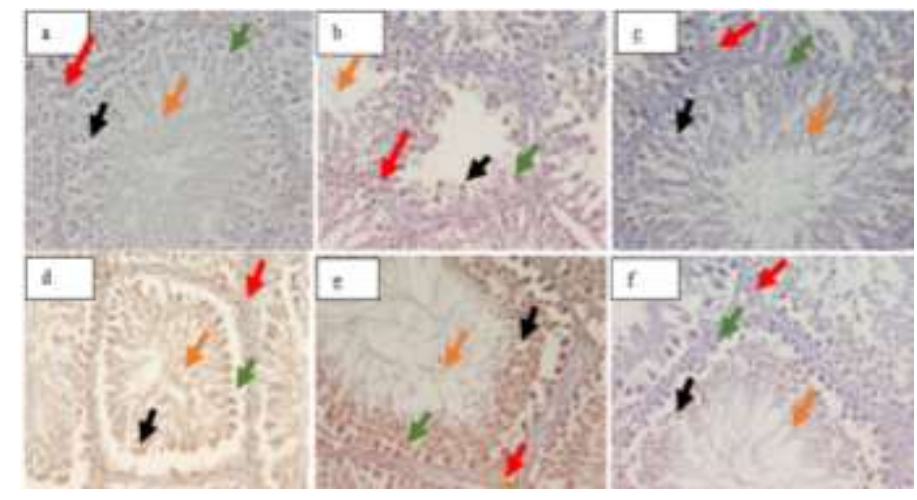

Figure 2. The result of caspase-3 immunohistochemical staining on 1 slice of transverse rat testis. The brown color of the Leydig nucleus indicates apoptosis.Note: (a) normal group; (b) diabetic rats; (c) normal group treated with $\mathrm{SP} 36 \mathrm{mg} / \mathrm{kgBW}$; (d) diabetic rats treated with SP $36 \mathrm{mg} / \mathrm{kgBW}$; (e) diabetic rats treated with SP $72 \mathrm{mg} / \mathrm{kgBW}$; (f) diabetic rats treated with SP $144 \mathrm{mg} / \mathrm{kgBW} \rightarrow$ Leydig cell $\rightarrow$ Spermatosit $\rightarrow$ Elongated spermatid $\rightarrow$ Sertoli cell.

The quality and quantity of sperm including spermatozoa count, sperm motility, organ index and apoptotic index showed improvement in the group of diabetic test animals given Spirulina platensis suspension compared to the STZ-induced diabetic test group. Spirulina platensis suspension at the dose of $144 \mathrm{mg} / \mathrm{kgBW}$ showed an antidiabetic effect and improved quality and quantity of the best spermatozoa compared to the suspension of Spirulina platensis at doses of $36 \mathrm{mg} / \mathrm{kgBW}$ and 72 $\mathrm{mg} / \mathrm{kg} \mathrm{BW}$.

\section{CONCLUSION}

The administrtion of Spirulina platensis suspension at a dose of $144 \mathrm{mg} / \mathrm{kgBW}$ can increased spermatozoa cell count, sperm motility, organ index and decreased expression of caspase-3 protein so that improve the quality and quantity of sperm in diabetic Wistar rats induced by STZ.

\section{ACKNOWLEDGEMENT}

We thank to PT Neoalgae Makmur Indonesia, Gresik, East Java which gave the plant material (Spirulina platensis powder) for the research.

\section{REFERENCES}

Al-Dhabi, N. A., Arasu, M.V., 2016. Quantification of phytochemicals from commercial Spirulina products and their antioxidant activities, Hindawi, 2016: 1-13.

Amaral, S., Moreno, A. J., Santos, M. S., Seiça, R., \& Ramalho-Santos, J., 2006. Effects of 
hyperglycemia on sperm and testicular cells of Goto-Kakizaki and streptozotocin-treated rat models for diabetes. Theriogenology, 66(9): 2056-2067.

Aybek, H., Aybek Z, Rota S, Sen N, Akbulut M, 2008. The effects of diabetes mellitus, age, and vitamin E on testicular oxidative stress, Fertil Sterile J., 90(3):755-80.

Ballester, J., Munoz M. C., Dominguez, J., Guinovart, J.J., Munoz, M.C., Rigau T., Rodriguez-Gil, J.E, 2004. Insulin-dependent diabetes affects testicular function by FSH- and LH-linked mechanisms. J Androl, 25(5): 706-719.

Bashandy, S.A.E., El-Awdan, S.A., Ebaid, H., Alhazza, I.M., 2016. Antioxidant Potential of Spirulina platensis Mitigates Oxidative Stress and Reprotoxicity Induced by Sodium Arsenite in Male Rats, Oxidative Medicine and Cellular Longevity, 2016: 1-8.

Bhat, V.B., Madyastha, K.M., 2000. C-phycocyanin: a potent peroxyl radical scavenger in vivo and in vitro. Biochem Biophy Res Comm, 275(1): 20-25.

Birben, E. ,Murat Sahiner, U., Sackesen, C., Erzurum, S., and Kalayci,O, 2012. Oxidative Stress and Antioxidant Defense. World Allergy Organ J, 5(1): 9-19.

Delfino M., Imbrogno, N., Elia J., Capogreco F, Mazzilli F., 2007. Prevalence of diabetes mellitus in male partners of infertile couples. Italy J Urol Nephrol, 59:131-135.

Deng, R., Chow, T.J., 2010, Hypolipidemic, Antioxidant and Antiinflamatory Activities of Microalgae Spirulina, Cardiovascular Therapeutics, 28: e33-e45.

El-Baz, F. K. Aly, H.F., El-Sayed, A.B., Mohamed, A.A., 2013, Role of Spirulina platensis in the control of glycemia in DM2 rats, International Journal of Scientific and Engineering Reasearch, 4 (12): 1-8.

El-Dosky G.E., Bashandy S.A., Alhazza I.M., Al-Othman Z., Mourad, Aboul-Soud M., Yusuf K., 2013. Improvement of Mercuric Chloride-Induced Testis Injuries and Sperm Quality Deteriorations by Spirulina platensis in Rats, PLOS One, 8(3): 1-9.

Elgawish, R., Abdelrazak, H. M. A., 2014, Effects of lead acetate on testicular function and caspase-3 expression with respect to the protective effect of cinnamon in albino rats, Toxicology Reports, 1(2014):795-801.

Firdiyani, F., Agustini, T.W., Ma'ruf, W.F., 2015. Ekstaksi Senyawa Bioaktif sebagai Antioksidan Alami Spirulina platensis Segar dengan Pelarut yang Berbeda, Jurnal Pengolahan Hasil Perikanan Indonesia, 18(1): 28-37.

Hanukoglu, I., 2006. Antioxidant protective mechanisms against reactive oxygen species (ROS) generated by mitochondrial P450 systems in steroidogenic cells, Drug Metab Rev. 38(1-2), 17196.

Haq, M., 2016. Pengaruh variasi konsentrasi pati ubi talas (Colocasia esculnta L.) sebagai Supending agent terhadap Sifat Fisik Suspensi Asam Mefenamat, Skripsi, Universitas Wahid Hasyim, Semarang.

International Diabetes Federation, 2003. Diabetes Atlas, Imprimerie L Vanmelle SA: Belgium.

Jiang, X., Chen, J., Zhang, C., Zhang, Z., Tan, Y., Feng, W., Skibba, M., Xin, Y., Cai, L., 2015. The Protective Effect of FGF21 on Diabetes-Induced Male Germ Cell Apoptosis Is Associated With Up-Regulated Testicular AKT and AMPK.Sirt1/PGC-1 $\alpha$ Signaling, Endocrinology, 156 (3): $1156-1170$.

Jungwirth, A., Diemer T., Dohle GR., Kopa Z, Krausz C., Tournaye H., 2012. EAU Guidelines on Male Infertility, Eur Urol, 62 (2): 324-2, 226-241.

Karunakaran, U., and Park, K.G., 2013. A systematic review of oxidative stress and safety of antioxidants in diabetes: focus on islets and their defense, Diabetes Metab J, 37(2):106-12.

Khaki, A., Fathiazad, F., Nouri, M., Khaki, A., Maleki, N.A., Khamnei, H.J., Ahmadi, P., 2010. Beneficial effects of quercetin on sperm parameters in streptozotocin- induced diabetic male rats. Phytother Res, 24(9): 1285-1291. 
Khaki, A.A., Hajhosseini, L.,Golzar, F.S., Ainechi, N., 2014. The Anti-oxidant Effect of Ginger and Cinnamon on Spermatogenesis Dysfunction of Diabetes Rats, African Journal of Traditional Alternative Medicine, 11(4), 1-8.

La Vignera, S., Condorelli, R., Vicari, E., D’Agata, R., Calogero, A. E., 2012. Diabetes mellitus and and sperm parameters. $J$ Androl, 33(2):145-153.

Layam, A., Reddy, C.L.K., 2007. Antidiabetic Property of Spirulina, Diabetologia Croatia, 35-2, 2933.

Mazo, V.K., Gmoshinshii, I.V., Zilova, I.S., 2004. Microalga spirulina in human nutrition, $V$. Opr. Pitan, 73 (1): 45-53.

Ozoguwu J. C., Obimba, K.C., Belonwu, C.D. \& Unakalamba, C. B., 2013. The pathogeness and pathophysiology of type 1 and type 2 diabetes mellitus, Journal of Physiology and Pathophysiology, 4 (4): 46-57.

Pankaj, P. P., 2016. Cell Suspension of Spirulina platensis Partially Attenuates Alloxan Induced Alterations in Carbohydrate and Lipid Metabolism Diabetic Mice, IJPSR, 7(7): 2805-2812.

Papaccio G, Pisanti FA, Latronico MV, Ammendola E, Galdieri M., 2000. Multiple low-dose and single high-dose treatments with streptozotocin do not generate nitric oxide. J. Cell Biochem, 77(1):82-91.

Plutzky, J., 2011. Macrovascular effects and safety issues of therapies for type 2 diabetes, $A m J$ Cardiol, 108(3): 25B-32B.

Rezvanfar, M.A., Sadrkhanlou, R. A., Ahmadi, A., Sadee,H.S., Rezvanfar, M.A., Mohammad, A., Salehnia, A., Abdollahi, M., 2008. Protection of cyclophosphamide-induced toxicity in reproductive tract histology, sperm characteristics, and DNA damage by an herbal source; evidence for role of free-radical toxic stress, Human and Experimental Toxicology, 27(12): 901910.

Sacarano, W.R., Messias, A.G., Oliva, S.U., Klinefelter, G.R., Kempinas, W.G., 2006. Sexual behaviour, sperm quantity and quality after shortterm streptozotocin-induced hyperglycaemia in rats, Int. J. Androl. 29(4): 482-488.

Shazly, M.O., Ahmed, K.A., Adel-Mawla., E., 2015. Therapeutic Effect of Spirulina platensis on Streptozotocin-Induced Diabetes Rats, Egypt. J. Comp. Path \&Clinic Path, 28(1): 18- 31.

Shrilatha B, Muralidhara, 2007. Early oxidative stress in testis and epididymal sperm in streptozotocin-induced diabetic mice: Its progression and genotoxic consequences, Reprod Toxicol, 23(4): 578-87.

Wang, L., Guo L., Zhang L., Zhou Y., He Q., Zhang Z., Wang M., 2013. Effects of Glucose Load and Nateglinide Intervention on Endothelial Function and Oxidative Stress, Journal of Diabetes Research, 2013: 1-9.

Widodo, F.T. 2009. Hubungan antara jumlah leukosit dengan motilitas sperma pada hasil analisa sperma pasien infertilitas di RSUP DR Kariadi Semarang. Laporan Akhir Penelitian. Universitas Diponegoro.

Won, H. N, Il, K. K., Hae, S.A., Mi, J.K, Kang, H.G, Jun, J.H., Gye, M.C., 2012. Effect of Spirulina maxima on spermatogenesis and steroidogenesis in streptozotocin-induced type I diabetic male rats, Food Chemistry, 134(1):173-179.

Yigit, F., Guerevin E.G., Basok B.I., Esener O.B.B., Keser O., 2016. Protective effect of Spirulina platensis against cell damage and apoptosis in hepatic tissue caused by high fat diet., Journal of Biochemical and Histochemistry, 91(3): 182-194.

Zheng, J., Inoguchi T., Sasaki, S., Maeda, Y., McCarty, M.F., Fujii, M., Ikeda, N., Kobayashi, K., Sonoda, N., Takayanagi, R., 2013, Phycocyanin and Phycocyanobilin from Spirulina platensis protect against Diabetic Nephropathy by Inhibiting Oxidative Stress, Am J Regul Integr Comp Physiol, 304: R110-R120. 